\title{
BACILLARY ANGIOMATOSIS: DESCRIPTION OF 13 CASES REPORTED IN FIVE REFERENCE CENTERS FOR AIDS TREATMENT IN RIO DE JANEIRO, BRAZIL
}

\begin{abstract}
SUMMARY
The aim of this case series was to describe the clinical, laboratory and epidemiological characteristics and the presentation of bacillary angiomatosis cases (and/or parenchymal bacillary peliosis) that were identified in five public hospitals of Rio de Janeiro state between 1990 and 1997; these cases were compared with those previously described in the medical literature.

Thirteen case-patients were enrolled in the study; the median age was 39 years and all patients were male. All patients were human immunodeficiency virus type 1 (HIV-1) infected and they had previous or concomitant HIV-associated opportunistic infections or malignancies diagnosed at the time bacillary angiomatosis was diagnosed. Median T4 helper lymphocyte counts of patients was 96 cells per $\mathrm{mm}^{3}$. Cutaneous involvement was the most common clinical manifestation of bacillary angiomatosis in this study. Clinical remission following appropriate treatment was more common in our case series than that reported in the medical literature, while the incidence of relapse was similar. The frequency of bacillary angiomatosis in HIV patients calculated from two of the hospitals included in our study was 1.42 cases per 1000 patients, similar to the frequencies reported in the medical literature. Bacillary angiomatosis is an unusual opportunistic pathogen in our setting.
\end{abstract}

KEYWORDS: Bacillary angiomatosis; Parenchymal bacillary peliosis; AIDS.

\section{INTRODUCTION}

Bacillary angiomatosis is a relatively uncommon emergent infectious disease, caused by two species of Gram negative bacilli: Bartonella (Rochalimaea) henselae and Bartonella (Rochalimaea) quintana ${ }^{11}$. It was first described in Human Immunodeficiency Virus (HIV) infected patient who presented with painless hardened subcutaneous nodules and fever $^{22}$. The name bacillary angiomatosis came from the vascular proliferation described on histologic examination of clinical specimens (skin, lymph nodes, bone, etc) and from the bacilli identified on WarthinStarry silver stain ${ }^{9}$. Skin and regional lymph nodes involvement are more frequently described ${ }^{11}$ but bacillary angiomatosis may affects a variety of internal organs including: liver, spleen, bone, oral mucosa, gastrointestinal tract, lung and brain ${ }^{5,7,8,15,26}$. It also occurs in other immunocompromised hosts, with similar clinical presentation, ${ }^{8,17,20}$ and a few cases have been reported in immunocompetent host $\mathrm{t}^{4,23}$.

In 1990, PERKOCHA et al. ${ }^{18}$ described a newly recognized clinical/ pathologic phenomenon in HIV infected patients: the bacillary peliosis hepatis. Later, SLATER et al. ${ }^{21}$ suggested that a better description of this pathologic phenomenon might be "parenchymal bacillary peliosis" because of the finding of peliotic lesions in the spleen as well as in the liver. These authors also related that only $B$. henselae was the etiologic agent of bacillary angiomatosis and parenchymal bacillary peliosis.

While bacillary angiomatosis is a potentially fatal illness ${ }^{5}$, it may be treated with relatively inexpensive and non-toxic antibiotics, if an early diagnosis is made ${ }^{9}$. However, if diagnosed later it is more difficult to treat, and often there is no clinical suspicion or appropriate diagnosis made in a timely fashion, resulting in significant morbidity and mortality in those who did not receive treatment ${ }^{25}$.

Thus, a better understanding of the clinical picture, optimal diagnostic approach, and appropriate treatment for bacillary angiomatosis is important to disseminate to physicians caring for AIDS patients; such information will allow for better success in treatment and avoid future cases of patients whose diagnosis only comes at the time of post mortem histopathology examination.

In this case series of bacillary angiomatosis we describe the demographics, clinical presentation, laboratory exams, and clinical course of 13 patients diagnosed in five hospitals of metropolitan Rio de Janeiro between 1990 to 1997, and contrast our findings with those found in the current medical literature. 


\section{PATIENTS AND METHODS}

We conducted a retrospective review of hospital charts of 13 patients with confirmed or suspected cases of bacillary angiomatosis and/or peliosis hepatis admitted to five public institutions which are reference centers for HIV/AIDS treatment in metropolitan Rio de Janeiro: Hospital Universitário Clementino Fraga Filho/Universidade Federal do Rio de Janeiro (HUCFF/UFRJ), Hospital Universitário Pedro Ernesto/ Universidade do Estado do Rio de Janeiro (HUPE/UERJ), Hospital Universitário Antonio Pedro/Universidade Federal Fluminense (HUAP/ UFF), Hospital Evandro Chagas/Fundação Oswaldo Cruz (HEC/ FIOCRUZ) and Hospital dos Servidores do Estado (HSE), between 1990 to 1997.

A standard form was completed on all patients, based on physician review of the hospital medical record and the histopathological report taken from biopsy, and demographics data, clinical presentation, laboratory examination results, and treatment and clinical outcome recorded.

\section{Definitions:}

A confirmed bacillary angiomatosis case was defined by the following histopathologic criteria: a) a lobular proliferation of small, round blood vessels with plump endothelial cells (with or without cytologic atypia) protruding into the vascular lumen; b) necrosis present within the centers of vascular lobules; c) a mixed inflammatory cell infiltrate with neutrophils and leukocytoclasis; d) granular amphophilic interstitial material revealing bacilli on silver staining (e.g. Warthin Starry) or electron microscopy or both ${ }^{12}$.

A probable case of bacillary angiomatosis was defined as a patient whose histhologic exam showed all criteria above described with the exception of criteria d.

Parenchymal lesions of bacillary peliosis revealed: a) dilated capillaries or multiple dilated, blood filled spaces and b) a myxoid stroma containing a mixture of inflammatory cells and clumps of granular amphophilic material (revealing bacilli on silver staining or electron microscopy) or both ${ }^{18}$.

An AIDS case was made according to the definition for adults and adolescents of Centers for Disease Control and Prevention (CDC) ${ }^{2}$; and stage of HIV infection was made using the revised CDC classification system, 1993. Mode of transmission of HIV was determined to be "unknown" if appropriate investigation revealed no definitive information" ${ }^{1}$.

Duration time from disease onset until the first medical evaluation was defined by the time period between the beginning of signs and symptoms related to bacillary angiomatosis and first medical evaluation.

Specific treatment was defined as the receipt of a macrolide (primarily erythromycin) antibiotic or tetracycline by the patient.

Clinical course was characterized in the following manner: a) remission: was the absence of all clinical signs and symptoms related to bacillary angiomatosis following appropriate treatment; b) clinical improvement: was defined as partial resolution of specific signs and symptoms following appropriate treatment, c) clinical deterioration: progressive deterioration of clinical picture resulting in death without specific treatment; d) relapse: reappearance of signs and symptoms related to bacillary angiomatosis following remission; e) therapeutic failure was defined as the absence of remission following appropriate treatment or the appearance of new signs and symptoms during appropriate treatment.

For those patients who died from a cause probably not related to bacillary angiomatosis, the survival period after diagnosis was considered; the occurrence of death was considered as unknown if a time period greater than six months had lapsed between the last registered patient visit in the hospital records and the review performed by one of the authors.

Statistical analysis: Data collected and frequency distribution were calculated using computer Program EPI-INFO, version 6,0, 1994, CDC, Atlanta, Georgia, United States.

\section{RESULTS}

Eleven patients with a confirmed diagnosis of bacillary angiomatosis (one also with peliosis hepatitis) and two with a probable diagnosis (one with isolated bone lesion and another with mucosae involvement) are included in this analysis: seven patients were from HUCFF/UFRJ, two from HUPE/UERJ, two from HUAP/UFF, one from HEC/FIOCRUZ and other from HSE. If we consider as numerator the number of cases of bacillary angiomatosis diagnosed at HUCFF and in HSE, between 1992 to 1997, and using as denominator the number of all AIDS cases notified in these hospitals during the same time period, the frequency of bacillary angiomatosis was 1.42 cases per 1000 patients.

Socio-demographics and epidemiological data are summarized in Table 1.

\section{Table 1}

Demographic and epidemiological characteristics of patients with bacillary angiomatosis

\begin{tabular}{|c|c|}
\hline Characteristics & Patients $(n=13)$ \\
\hline $\begin{array}{l}\text { Age, mean; median (range) } \\
\text { (years) }\end{array}$ & $38.5 \pm 7.6 ; 39(27$ to 56$)$ \\
\hline Sex, $\%$ male & 100 \\
\hline Race, \% white & $76.9(10 / 13)$ \\
\hline Residence, $\%$ from Rio de Janeiro & $84.6(11 / 13)$ \\
\hline $\begin{array}{l}\text { Monthly family income, mean; } \\
\text { median (MI)* }\end{array}$ & $5.2 \pm 0.8 ; 5(4.5$ to 6$)$ \\
\hline HIV infection (\%) & 100 \\
\hline Homosexual (\%) & $53.8(7 / 13)$ \\
\hline Heterosexual (\%) & $38.5(5 / 13)$ \\
\hline History of cat trauma $(\%)$ & $25(1 / 4)$ \\
\hline Alcohol intake $(\%)$ & $27.3(3 / 11)$ \\
\hline
\end{tabular}

$*$ minimal income $=70$ US $\$$ 


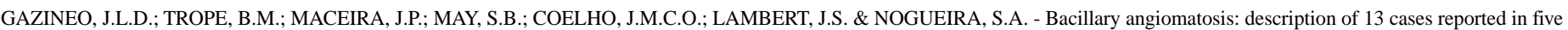
reference centers for AIDS treatment in Rio de Janeiro, Brazil. Rev. Inst. Med. trop. S. Paulo, 43(1):1-6, 2001.

The patients included in this case series often presented with concomitant opportunistic infections and/or neoplasm associated with $\mathrm{HIV}$ at the time of the bacillary angiomatosis diagnosis. Ten of 13 patients (76.9\%) had C category classification according to CDC and $23.1 \%$ (3/ 13) category B. Eight of 13 patients $(61.5 \%)$ received antiretroviral therapy and $69.2 \%$ (9/13) prophylaxis for Pneumocystis carinii with trimethoprim-sulfamethoxazole (TMP-SMX). No patients received prophylaxis for atypical mycobacteria. The frequency and type of opportunistic infections and/or neoplasm associated to HIV are presented in Table 2.

Laboratory results of patients with bacillary angiomatosis showed that the mean and median CD4 ${ }^{+} \mathrm{T}$ cell count were 85.8 cells $/ \mathrm{mm}^{3} \pm 73.9$ and 96 cells $/ \mathrm{mm}^{3}$ respectively, the mean and median alkaline phosphatase were 580.87 U.I./L \pm 630.34 and 395.5 U.I./L respectively while the mean and median aspartate aminotransferase were 78.54 U.I./L \pm 73.70 and 46 U.I./L respectively. All patients were anaemic and the mean and median hematocrit were $24.4 \% \pm 6.2$ and $26 \%$ respectively.

Ten of 13 patients (76.9\%) presented with skin or subcutaneous lesions, and one of these also had intestinal, splenic, and pancreatic involvement

Table 2

Frequency of opportunistic infections and/or neoplasms found in association with diagnosis of bacillary angiomatosis

Opportunistic infections and/or

neoplasms related to HIV*

Frequency

Oral candidiasis

Esophageal candidiasis

$76.92 \%(10 / 13)$

$30.76 \%(4 / 13)$

Pneumocystis carinii pneumonia

$15.38 \%(2 / 13)$

Kaposi's sarcoma

$15.38 \%(2 / 13)$

Cerebral toxoplasmosis

Cytomegalovirus

$15.38 \%(2 / 13)$

$7.69 \%(1 / 13)$

Hodgkins lymphoma

$7.69 \%(1 / 13)$

*Each patient may have presented with one or more opportunistic infections or neoplasm prior to or concomitant with diagnosis of bacillary angiomatosis.

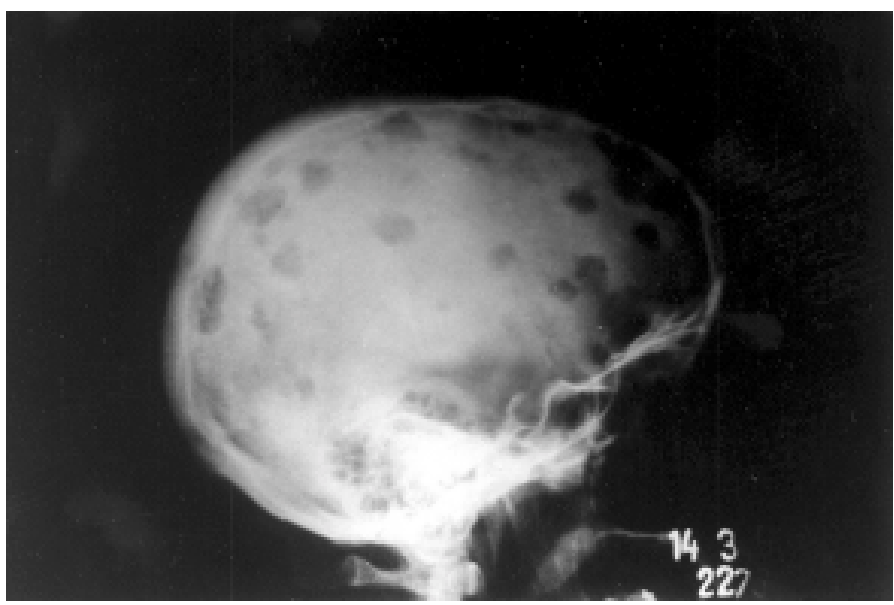

Fig. 1 - Osteolytic lesions due to bacillary angiomatosis. with concomitant parenchymal bacillary peliosis identified at autopsy Three patients had no skin or subcutaneous lesions: one had bone involvement (Fig. 1); one had an inflammatory soft tissue tumour; and one had mucosal involvement of the tongue. The clinical picture of patients with bacillary angiomatosis in this study is presented in Table 3.

The median duration time from disease onset until the first medical evaluation was 30 days, with mean of $50.77 \pm 41.08$ days and range of 14 to 120 days. The median time between the first medical consultation for this problem and the diagnosis of bacillary angiomatosis was 94 days, with mean of $128.92 \pm 100.60$ days and range of 23 to 300 days. The histopathologic diagnoses (Fig. 2) were performed prior to death in $69.2 \%$ of cases $(9 / 13)$ and in $30.8 \%$ (4/13), after death.

Appropriate treatment was initiated in 76.9\% (10/13) of patients, with median duration of treatment of eight weeks, mean of $8.7 \pm 3.2$ weeks, and range of two to 12 weeks. Of these ten patients who received treatment, 8 received erythromycin and one each received clarithromycin and tetracycline. One patient received, following erythromycin, doxycycline for two weeks due to gastrointestinal intolerance from erythromycin, and subsequently received clarithromycin suppressive treatment.

Table 3

Frequency of signs and symptoms in 13 patients with bacillary angiomatosis

Signs and/or symptoms

Frequency

Fever

$84.6 \%(11 / 13)$

Skin lesions

$76.9 \%(10 / 13)$

Weight loss

$69.2 \%(9 / 13)$

Anorexia

$61.5 \%(8 / 13)$

Hepatomegaly

$61.5 \%(8 / 13)$

Lymphadenopathy

$53.8 \%(7 / 13)$

Diarrhea

$53.8 \%(7 / 13)$

Malaise

$46.2 \%(6 / 13)$

Nausea or vomiting

$38.5 \%(5 / 13)$

Splenomegaly

$23.1 \%(3 / 13)$

Bone pain

$15.4 \%(2 / 13)$

Night sweats

$15.4 \%(2 / 13)$

Enlargement of soft tissues

$15.4 \%(2 / 13)$

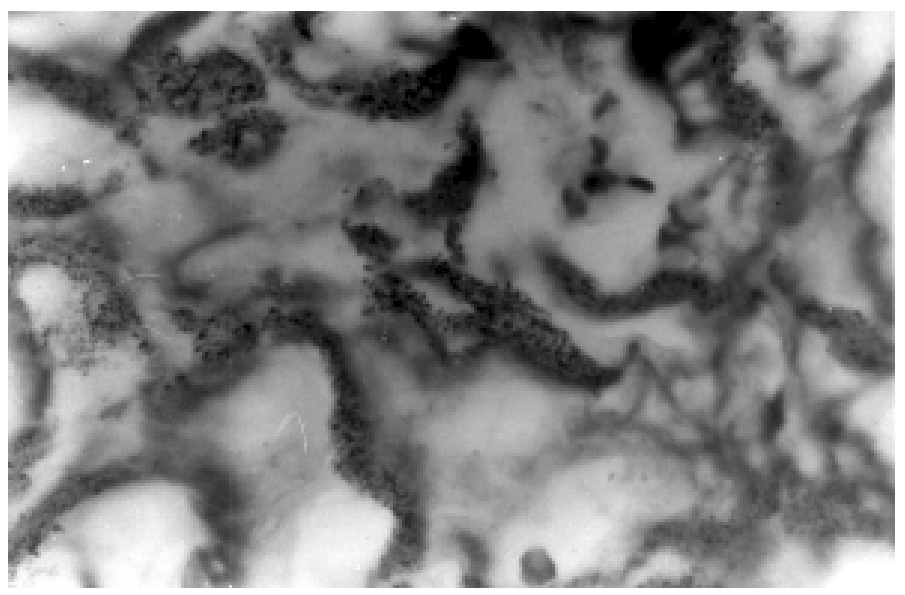

Fig. 2 - Skin (Warthin-Starry X 1000) - Presence of clusters of silver staining bacilli. 


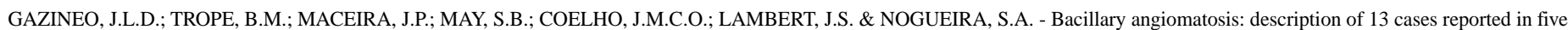
reference centers for AIDS treatment in Rio de Janeiro, Brazil. Rev. Inst. Med. trop. S. Paulo, 43(1):1-6, 2001.

Seven of 13 patients went into remission $(53.8 \%)$, three into clinical improvement $(23.1 \%)$ and three into clinical deterioration $(23.1 \%)$. Of ten patients who received appropriate treatment, seven went into remission, and the frequency of therapeutic failure was $30 \%(3 / 10)$. In addition, among those patients who had remissions, 20\% (2/10) relapsed and were re-treated with doxycycline and rifampin.

Eight of 13 patients went into death (61.5\%), being $28.6 \%$ of them (2/7) probably related to bacillary angiomatosis (in one patient the cause of death was unknown). The median time of survival after the diagnosis of bacillary angiomatosis was 10.5 months, mean of $10.75 \pm 5.32$ months and range of five to 17 months. Seven of 13 patients $(53.8 \%)$ had opportunistic infections after the diagnosis of bacillary angiomatosis.

\section{DISCUSSION}

Bacillary angiomatosis is an emergent infectious disease, and is included in category B of the CDC revised system for classification of HIV infection and surveillance for AIDS cases in adults and adolescents ${ }^{2}$. However, as previously described by MOHLE-BOETANI et al. ${ }^{14}$ and PLETTENBERG et $a l .{ }^{19}$, the majority of patients with this infection present with advanced stages of immunosuppression (CD4 ${ }^{+} \mathrm{T}$ cell count less than 200 cells $/ \mathrm{mm}^{3}$ ); some authors have suggested that bacillary angiomatosis should be given a category $\mathrm{C}$ case definition ${ }^{14}$.

Bacillary angiomatosis and HIV is a relatively rare disease: PLETTENBERG et $a l .{ }^{19}$ described 21 cases from 22 AIDS reference centers in Germany and found a frequency of 1.2 cases per 1,000 HIV infected patients between 1990 to 1996 . Our data gives a similar frequency in incidence data reviewed from two hospitals in Rio de Janeiro (1.42 cases per 1,000 patients). However, because of the retrospective nature of our study, all cases of bacillary angiomatosis may not have been included in this analysis; additionally, underreporting of AIDS cases in our setting is common, which may affect our incidence data. Other patients with bacillary angiomatosis, for example those who received transplants ${ }^{8}$, those with neoplasms ${ }^{13}$, those receiving immunosuppressive treatments ${ }^{17,20}$, and normal patients who had contact with cats $^{4,23}$ as described in medical literature were not identified in our study.

Concerning the sex distribution of the patients with bacillary angiomatosis, all patients were men (Table 1), similar to the description in the medical literature ${ }^{14,19}$. This likely represents the distribution of HIV infection in the population, rather than a predilection for men over women ${ }^{1}$. The median age (39 years) (Table 1) is identical to what was described by PLETTENBERG et al..$^{19}$ and slightly older than that reported by MOHLE-BOETANI et al. ${ }^{14}$ (37 years) who performed a case-control study. This age range likely reflects the age distribution of HIV infection in the population studied.

In our case series of bacillary angiomatosis, trauma related to cat injury was reported by $25 \%$ (1/4) of our patients whose medical records mentioned contact with cats. This frequency is low when compared to other reports in the medical literature ${ }^{10,24}$. Unfortunately this data was not collected prospectively from our study, and contact with cats was not a routine question obtained in most of our patients included in the analysis.

All patients included in this study had prior (or concomitant) opportunistic infections (Table 2) suggesting they had more advanced stages of HIV infection. This frequency of AIDS was lower to that reported (94\%) by MOHLE-BOETANI et al. ${ }^{14}$. In their study, patients with bacillary angiomatosis had statistically more chance of having AIDS when compared to controls (HIV infected patients without bacillary angiomatosis). Eight of our patients (61.5\%) used cotrimoxazole for $P$. carinii prophylaxis (primary or secondary) possibly suggesting that TMPSMX does not provide protection against bacillary angiomatosis or peliosis. KOEHLER et al. ${ }^{10}$ and MOHLE-BOETANI et al. ${ }^{14}$ made a similar observation. None of our patients had received azithromycin or clarithromycin for primary prophylaxis against atypical mycobacteria, as it was not the standard of care at the time of the study, and has just been recommended more recently ${ }^{3}$.

The median $\mathrm{CD}^{+} \mathrm{T}$ cell count was 96 cells $/ \mathrm{mm}^{3}$, and none of these patients had count above 200 cells $/ \mathrm{mm}^{3}$, indicating a group with more advanced immunosuppression; similarly to the studies of MOHLEBOETANI et $a l .{ }^{14}$ and PLETTENBERG et al. ${ }^{19}$, where median CD4 ${ }^{+} \mathrm{T}$ cell counts of 21 and 30 cells $/ \mathrm{mm}^{3}$, respectively, were reported. The median value of alkaline phosphatase was 395.5 U.I./L, higher than values reported from the cases of KOEHLER et al. ${ }^{10}$ and MOHLE-BOETANI et $a l .{ }^{14}$ (190 and 192 U.I./L, respectively). In this study a statistical association, in both univariate and multivariate analysis, was found between bacillary angiomatosis and elevated alkaline phosphatase ( $\geq 153$ U.I./L), even after controlling for anaemia and $\mathrm{CD}^{+} \mathrm{T}$ cell count. Our patients had a lower hematocrit $(26 \%)$ when compared to other studies ${ }^{10,14}$.

Regarding the clinical picture of bacillary angiomatosis, MOHLEBOETANI et al.${ }^{14}$ reported that the cases of bacillary angiomatosis were more commonly associated with fever, anorexia, lymphadenopathy, hepatomegaly, and splenomegaly when compared to controls; but KOEHLER et al. ${ }^{10}$ reported that their cases of bacillary angiomatosis were more likely than the controls (without bacillary angiomatosis) to have poor appetite, weight loss and recurrent fevers in the last six months preceding their diagnosis. In our cases, the most frequent signs and symptoms were: fever, weight loss, anorexia, hepatomegaly and lymphadenopathy (Table 3), similar to other descriptions in the literature ${ }^{10,14}$, and these symptoms and signs disappeared after appropriate treatment, suggesting they were related to bacillary angiomatosis and not to other opportunistic infections which presented simultaneously in some patients.

The median of duration time from disease onset until the first medical evaluation was 30 days; similar to the findings in a case controlled study performed by MOHLE-BOETANI et al. ${ }^{14}$ (28 days). However the median time between the first consultation and the diagnosis of bacillary angiomatosis was 94 days, which is three times longer than that reported by MOHLE-BOETANI et al. ${ }^{14}$. This reflects the lack of suspicion of the diagnosis of bacillary angiomatosis among the Brazilian caretakers and a delay in obtaining a tissue biopsy to perform an appropriate histopathologic exam.

Ten of 13 patients $(76.9 \%)$ presented with skin and/or with subcutaneous involvement, higher than that reported by MOHLEBOETANI et al. ${ }^{14}(55 \%)$ but lower than that reported by PLETTENBERG et al. ${ }^{19}$ (90\%). Osteolytic lesions were seen on bone X-ray of the two patients who complained of bone pain. Thus, it is important to look for bone lesions in all patients with bacillary angiomatosis with similar complaints because treatment of bone lesions requires a longer duration 


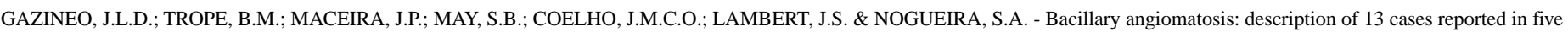
reference centers for AIDS treatment in Rio de Janeiro, Brazil. Rev. Inst. Med. trop. S. Paulo, 43(1):1-6, 2001.

of appropriate treatment than if only skin lesions were present, according to KOEHLER \& TAPPERO ${ }^{11}$.

The frequency of lymph node involvement in the study of MOHLEBOETANI et al. ${ }^{14}$ was $26 \%$. In our present series of bacillary angiomatosis, while admittedly not confirmed by histopathologic findings, lymphadenopathy was present in $53.8 \%$ (7/13) of our patients (Table 3).

Liver and spleen involvement in bacillary angiomatosis varied from $12 \%$ to $26 \%{ }^{10,14}$. Nine of our patients $(69.2 \%)$ presented with hepatomegaly and/or splenomegaly but liver and spleen lesions suspected secondary to bacillary angiomatosis were not confirmed by biopsy. One patient who underwent autopsy had evidence of parenchymal bacillary peliosis. This same patient also showed intestinal and pancreatic involvement. Intestinal lesions of bacillary angiomatosis are uncommon ${ }^{7,26,27}$. Our literature search found no mention of pancreatic involvement in bacillary angiomatosis, which is likely very rare.

A specific etiologic diagnosis was not made in any of our patients as there was no adequate system for microbiological identification (lysiscentrifugation); and no laboratory facilities were available to demonstrate the agent of bacillary angiomatosis by polymerase chain reaction, immuno-histochemistry or serology in our hospitals. However all patients described in this study did have the diagnosis of bacillary angiomatosis made by histophatologic examination.

Among patients treated with appropriate antibiotics, a 70\% (7/10) frequency of remission was achieved, similar to that reported by PLETTENBERG et al. ${ }^{19}(65 \%)$. Besides a therapeutic failure of $30 \%$ (3/ $10)$ was found in our casuistry. The reasons for $30 \%$ non-response may be related to inadequate absorption of drugs, inadequate adherence, an inadequate course of therapy, a lack efficacy of the antibiotic ${ }^{16}$, or to resistance of Bartonella spp to the antibiotics used ${ }^{6}$.

Two of 10 treated patients (20\%) relapsed, similar to the frequency reported by PLETTENBERG et al. ${ }^{19}$ (23.8\%). The relapses may be due to the absence of a bactericidal effect of the antibiotic ${ }^{16}$; to the possibility of re-infection ${ }^{6}$, or to the possibility of co-infection by more than one species of Bartonella, with one of them resistant to the antibiotic used ${ }^{6}$. The two patients who relapsed subsequently had remission following treatment with doxycicline and rifampin.

We conclude that bacillary angiomatosis is a relatively uncommon infectious disease in our setting, an opportunistic disease in advanced AIDS patients, where an earlier diagnosis can potentially lead to a better outcome.

\section{RESUMO}

\section{Angiomatose bacilar: descrição de 13 casos relatados em cinco centros de referência para tratamento de AIDS no Rio de Janeiro, Brasil.}

Esta série de casos foi conduzida com o objetivo de descrever a apresentação clínica, as características epidemiológicas, os exames laboratoriais e a evolução dos casos de angiomatose bacilar (e/ou peliose parenquimatosa bacilar) ocorridos em cinco hospitais públicos do Rio de Janeiro, no período de 1990 a 1997, comparando a casuística encontrada com a relatada na literatura médica.

Foram incluídos 13 pacientes com mediana de idade de 39 anos, sendo todos pertencentes ao sexo masculino. Todos os pacientes apresentaram infecções oportunistas e/ou neoplasias associadas ao vírus da imunodeficiência humana (HIV-1) anteriores (ou concomitantes) ao diagnóstico de angiomatose bacilar. A mediana da contagem de linfócitos T Helper encontrada foi de 96 células por $\mathrm{mm}^{3}$. O acometimento cutâneo foi a apresentação clínica de angiomatose bacilar mais freqüente deste estudo. A freqüência de remissão após tratamento específico foi discretamente maior do que a relatada na literatura médica, enquanto a de recidiva foi semelhante. A frequiência de angiomatose bacilar entre indivíduos infectados pelo HIV de dois hospitais do Rio de Janeiro foi de 1,42 casos por 1.000 pacientes, semelhante ao relatado na literatura médica e sugestivo de que a angiomatose bacilar é relativamente incomum em nosso meio.

\section{ACKNOWLEDGEMENTS}

We would like to acknowledge the physicians who allowed us to use the data of their patients in this series of cases: Dr. Valéria Ribeiro Gomes (HUPE/UERJ), Prof. Dirce Bonfim (HUPE/UERJ), Dr. Magda de Souza da Conceição (HUPE/UERJ), Dr. Arley da Silva Jr. (Serviço de Patologia Oral/UFRJ), Dr. Ianick Souto Martins (HUCFF/UFRJ), Dr. Marcello Vieira (HUCFF/UFRJ), Dr. Ana Pia Esporcatte (HUCFF/UFRJ), Dr. Vinicius de Morais (HUCFF/UFRJ), Dr. Otília Helena Lupi da Rosa Santos (HUAP/UFF), Prof. Ana Bazin (HUAP/UFF), Dr. Tânia Blanco (HEC/FIOCRUZ), Dr. Beatriz Grinsztejn (HEC/FIOCRUZ) and Dr. Esaú Custódio João Filho (HSE).

\section{REFERENCES}

1. BRASIL. MINISTÉRIO DA SAÚDE - Coordenação Nacional de Doenças Sexualmente Transmissíveis e AIDS. AIDS Bol. Epidemiol., (6)1997.

2. CDC - 1993 Revised classification system for HIV infection and expanded surveillance case definition for AIDS among adolescents and adults. M.M.W.R., 41(RR-17): 1-19, 1992.

3. CDC - 1997 USPHS/IDSA guidelines for the prevention of opportunistic infections in persons infected with human immunodeficiency virus. M.M.W.R., 46(RR-12): 146, 1997.

4. COCKERELL, C.J.; BERGSTRESSER, P.R.; MYRIE-WILLIAMS, C. \& TIERNO, P.M - Bacillary epithelioid angiomatosis occurring in an immunocompetent individual. Arch. Derm., 126: 787-790, 1990.

5. COCKERELL, C.J.; WHITLOW, M.A.; WEBSTER, G.F. \& FRIEDMAN-KIEN, A.E. Epithelioid angiomatosis: a distinct vascular disorder in patients with the acquired immunodeficiency syndrome or AIDS-related complex. Lancet, 2: 654-656, 1987.

6. COLSON, P.; LEBRUN, L.; DRANCOURT, M. et al. - Multiple recurrent bacillary angiomatosis due to Bartonella quintana in an HIV-infected patient. Europ. J. Microbiol. infect. Dis., 15: 178-179, 1996.

7. HUH, Y.B.; ROSE, S.; SCHOEN R.E. et al. - Colonic bacillary angiomatosis. Ann. intern. Med., 124: 735-737, 1996.

8. KEMPER, C.A.; LOMBARDI, C.M.; DERESINSKI, S.C. \& TOMPKINS, L.S. - Visceral bacillary epithelioid angiomatosis: possible manifestations of disseminated cat scratch disease in the immunocompromised host: a report of two cases. Amer. J. Med., 89: 216-222, 1990. 


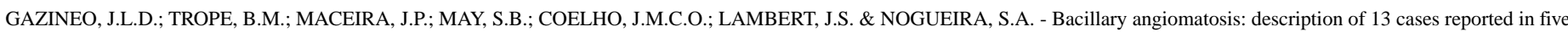
reference centers for AIDS treatment in Rio de Janeiro, Brazil. Rev. Inst. Med. trop. S. Paulo, 43(1):1-6, 2001.

9. KOEHLER, J.E.; LeBOIT, P.E.; EGBERT, B.M. \& BERGER, T.G. - Cutaneous vascular lesions and disseminated cat-scratch disease in patients with the acquired immunodeficiency syndrome (AIDS) and AIDS-related complex. Ann. intern. Med., 109: 449-455, 1988.

10. KOEHLER, J.E.; SANCHEZ, M.A.; GARRIDO, C.S. et al. - Molecular epidemiology of Bartonella infections in patients with bacillary angiomatosis-peliosis. New Engl. J. Med., 337: 1876-1883, 1997.

11. KOEHLER, J.E. \& TAPPERO, J.W. - Bacillary angiomatosis and bacillary peliosis in patients infected with human immunodeficiency virus. Clin. infect. Dis., 17: 612624, 1993.

12. LeBOIT, P.E.; BERGER, T.G.; EGBERT, B.M. et al. - Bacillary angiomatosis: the histopathology and differential diagnosis of a pseudoneoplastic infection in patients with human immunodeficiency virus disease. Amer. J. surg. Path., 13: 909-920, 1989.

13. MILDE, P.; BRUNNER, M.; BORCHARD, F. et al. - Cutaneous bacillary angiomatosis in a patient with chronic lymphocytic leukemia. Arch. Derm., 131: 933-936, 1995.

14. MOHLE-BOETANI, J.C.; KOEHLER, J.E.; BERGER, T.G. et al. - Bacillary angiomatosis and bacillary peliosis in patients infected with human immunodeficiency virus: clinical characteristics in a case-control study. Clin. infect. Dis., 22: 794-800, 1996.

15. MOORE, E.H.; RUSSELL, L.A.; KLEIN, J.S. et al. - Bacillary angiomatosis in patients with AIDS: multiorgan imaging findings. Radiology, 197: 67-72, 1995.

16. MUSSO, D.; DRANCOURT, M. \& RAOULT, D. - Lack of bactericidal effect of antibiotics except aminoglycosides on Bartonella (Rochalimaea) henselae. J. Antimicrob. Chemother., 36: 101-108, 1995.

17. MYERS, S.A.; PROSE, N.S.; GARCIA, J.A. et al. - Bacillary angiomatosis in a child undergoing chemotherapy. J. Pediat., 121: 574-578, 1992.

18. PERKOCHA, L.A.; GEAHAN, S.M.; YEN, T.S.B. et al. - Clinical and pathological features of bacillary peliosis hepatis in association with human immunodeficiency virus infection. New Engl. J. Med., 323: 1581-1586, 1990.
19. PLETTENBERG, A.; RASOKAT, H.; KALIBE, T. et al. - Bacillary angiomatosis in HIV-infected patients. An epidemiological and clinical study. In: WORLD AIDS CONFERENCE, 12, 1998, Geneva. Abstracts. p. 824.

20. SCHWARTZ, R.A.; GALLARDO, M.A.; KAPILA, R. et al. - Bacillary angiomatosis in a HIV seronegative patient on systemic steroid therapy. Brit. J. Derm., 135: 982987, 1996.

21. SLATER, L.N.; WELCH, D.F. \& MIN, K.-W. - Rochalimaea henselae causes bacillary angiomatosis and peliosis hepatis. Arch. intern. Med., 152: 602-606, 1992.

22. STOLER, M.H.; BONFIGLIO, T.A.; STEIGBIGEL, R.T. \& PEREIRA, M. - An atypical subcutaneous infection associated with acquired immunodeficiency syndrome. Amer. J. clin. Path., 80: 714-718, 1983.

23. TAPPERO, J.W.; KOEHLER, J.E.; BERGER, T.G. et al. - Bacillary angiomatosis and bacillary splenitis in immunocompetent adults. Ann. intern. Med., 118: 363-365, 1993.

24. TAPPERO, J.W.; MOHLE-BOETANI, J.; KOEHLER, J.E. et al. - The epidemiology of bacillary angiomatosis and bacillary peliosis. J. Amer. med. Ass., 269: 770-775, 1993.

25. TROPE, B.M. \& MACEIRA, J.P. - Angiomatose epitelióide bacilar: outra infecção oportunista em pacientes com SIDA. An. bras. Derm., 67: 47-49, 1992.

26. TUUR, S.M.; MACHER, A.M. \& ANGRITT, P. - AIDS case for diagnosis series. Milit. Med., 153: M57-M64, 1988.

27. WALFORD, N.; VAN DER WOUW, P.A.; DAS, P.K.; TEN VELDEN, J.J.A.M. \& HULSEBOSCH, H.J. - Epithelioid angiomatosis in acquired immunodeficiency syndrome: morphology and differential diagnosis. Histopathology, 16: 83-88, 1990.

Received: 20 March 2000

Accepted: 15 August 2000 